\title{
КОНЦЕПТУАЛЬНІ ПІДХОДИ ДО ЦИФРОВОЇ ТРАНСФОРМАЦІЇ ОСВІТИ І НАУКИ
}

У статті розглядаються концептуальні підходи цчифрової трансформації освітньої галузі. Оскільки державою приділяється велику увагу запровадження в усі сфери державного управління сучасних інформачійних технологій, тому иче стосується також і державного управління освітньою галуззю.

Виходячи з викладеного матеріалу, наразі актуальними важливі питання теоретикометодологічного обтрунтування конщептуальних підходів до цииррової трансформацї державного управління освітньою галуззю через формування єдиного освітнього інформаційного середовища в контексті розширення концепиії електронного урядування.

Описано, щуо у травні 2021 року МОН підготувало та пропонує для громадського обговорення проєкт Концепиії цчифрової трансформації освіти і науки на період до 2026 року.

Визначено, шьо наявність такої системи значно б полегшила роботу Міністерству освіти у науки Украйни, як центрального органу виконавчої влади, щчо забезпечує формування та реалізує державну політику у сферах освіти і науки, наукової, науково-технічної та інноваційної діяльності, трансферу (передачі) технологій, а також забезпечує формування та реалізацію державної політики у сфері здійснення державного нагляду (контролю) за діяльністю закладів освіти, підприємств, установ та організаиій, які надають послуги у сфері освіти або провадять іншу діяльність, пов 'язану з наданням таких послуг, незалежно від їх підпорядкування і форми власності.

Досліджено, що реалізація запропонованої Концепиї дасть можливість здійснити ијиррову трансформацію закладів освіти, в яких педагогічні та науково-педагогічні прачівники, а також здобувачі освіти володіють ичифровими компетентностями, забезпечені обладнаними ичифровими, сучасними робочими місиями, а також доступом до циифрового контенту для персонального розвитку, навчання впродовж життя.

Ключові слова: сочіальні системи, публічне управління, освітня галузь, електронне урядування, інформаційний ресурс, освітнє інформаційно середовище, структурно-об'єктний підхід.

Н.А. ДУРМАН

Херсонский национальный технический университет ORCID: 0000-0002-3775-205X

Е.Л. ДУРМАН

Херсонский национальный технический университет ORCID: 0000-0001-7829-9944

\section{КОНЦЕПТУАЛЬНЫЕ ПОДХОДЫ К ЦИФРОВОЙ ТРАНСФОРМАЦИИ ОБРАЗОВАНИЯ И НАУКИ}

В статье рассматриваются концептуальные подходы ичифровой трансформации образования. Поскольку государством уделяется большое внимание внедрению во все сферь государственного управления современных информационных технологий, поэтому это касается такље $u$ государственного управления образовательной отраслью.

Исходя из изложенного материала, пока актуальныли важные вопросы теоретикометодологического обоснования концеппуальных подходов $\kappa$ ичифровой трансформации государственного управления образовательной отраслью через формирование единой образовательной информационной среды в контексте расширения концепщии электронного управления.

Описано, что в мае 2021 МОН Украинь подготовило и предлагает для общественного обсуждения проект Конщчепции цุифровой трансформации образования и науки на период до 2026 года.

Определено, что наличие такой системы значительно бы облегчило работу Министерству образования у науки Украины, как центрального органа исполнительной власти, который обеспечивает формирование и реализует государственную политику в сферах образования и науки, научной, научнотехнической и инновачионной деятельности, трансфера (передачи) технологий, а также обеспечивает 
формирование и реализащию государственной политики в сфере осуществления государственного надзора (контроля) за деятельностью учебных заведений, предприятий, учреждений и организаций, предоставляющих услуги в сфере образования или осуществляют иную деятельность, связанную с предоставлением таких услуг, независимо от их подчинения и формы собственности.

Доказано, что реализация предложенной Концепциии позволит осуществить циифровую трансформацию учебных заведений, в которых педагогические и научно-педагогические работники, а также соискатели образования обладают ичифровыми компетенцииями, обеспечены оборудованными циифровыми, современными рабочими местами, а также доступ к ичфровому контенту для персонального развития, обучения в течение жизни.

Ключевые слова: сочиальные системы, публичное управление, сфера образования, электронное управление, информационный ресурс, образовательной информационной среды, структурно-объектный подход.

M. DURMAN

Kherson National Technical University ORCID: 0000-0002-3775-205X

O. DURMAN

Kherson National Technical University ORCID: 0000-0001-7829-9944

\section{CONCEPTUAL APPROACHES TO DIGITAL TRANSFORMATION OF EDUCATION AND SCIENCE}

The article discusses conceptual approaches to digital transformation of education. Since the state pays great attention to the introduction of modern information technologies in all areas of public administration, therefore this also applies to public administration of the educational industry.

Based on the above material, important issues of theoretical and methodological substantiation of conceptual approaches to the digital transformation of public administration in the educational industry through the formation of a unified educational information environment in the context of expanding the concept of egovernment are still relevant.

It is described that in May 2021 the Ministry of Education and Science prepared and proposes for public discussion a draft Concept for the digital transformation of education and science for the period up to 2026.

It has been determined that the presence of such a system would greatly facilitate the work of the Ministry of Education of Ukraine for Science, as the central executive body that ensures the formation and implements of state policy in the fields of education and science, scientific, scientific, technical and innovative activities, transfer (transfer) of technologies, and also ensures the formation and implementation of state policy in the field of state supervision (control) over the activities of educational institutions, enterprises, institutions and organizations that provide services in the field of education or carry out other activities related to the provision of such services, regardless of their subordination and form of ownership ...

It has been proved that the implementation of the proposed Concept will allow for the digital transformation of educational institutions in which teaching and research and teaching staff, as well as education seekers have digital competencies, are provided with equipped digital, modern workplaces, as well as access to digital content for personal development, training in the course of life.

Key words: social systems, public administration, education, e-government, information resource, educational information environment, structural-object approach.

\section{Постановка проблеми}

На сьогоднішній день українська держава приділяє велику увагу запровадження в усі сфери державного управління сучасних інформаційних технологій. Це стосується також і державного управління освітньою галуззю.

Так, наприклад, одним із кроків є запровадження Єдиної державної електронної бази 3 питань освіти [1], що включає в себе набір засобів та інструментів, призначених для автоматизації управлінської діяльності органів управління освітою всіх рівнів, включаючи середню та дошкільну освіту.

В той же час на сьогодні не існує єдиного цифрового середовища, яке об'єднує всіх суб'єктів освітньої та наукової діяльності, яке б давало можливість отримувати різноманітну та актуальну, достовірну та повну інформацію про діяльність освітніх структур, посадових осіб, викладачів тощо.

Така система б значно полегшила роботу Міністерству освіти у науки України, як центрального органу виконавчої влади, що забезпечує формування та реалізує державну політику у сферах освіти i науки, наукової, науково-технічної та інноваційної діяльності, трансферу (передачі) технологій, а також забезпечує формування та реалізацію державної політики у сфері здійснення державного нагляду 
(контролю) за діяльністю закладів освіти, підприємств, установ та організацій, які надають послуги у сфері освіти або провадять іншу діяльність, пов'язану з наданням таких послуг, незалежно від їх підпорядкування і форми власності [2].

Аналіз останніх досліджень і публікацій

Поставлену проблему можна розглядати 3 позиції державного управління, включаючи два аспекти цієї проблеми - власне, аспект формування механізмів державного управління освітньою галуззю, а також аспект застосування сучасних інформаційних технологій при проектуванні систем управління, що використовуються для реалізації цього механізму.

Серед провідних науковців, що розглядали державне управління, в тому числі й освітньою галуззю, $з$ загальносистемних позицій можна відзначити Н.Р. Нижник [3], В.Д. Бакуменка [4], М.Х. Корецького [5], Д.І. Дзвінчука [6], І.П. Лопушинського [7] тощо.

Впровадженням системного підходу та інформаційних технологій для проектування систем управління різними галузями з точки зору державного управління займалися П.І. Бідюк [8], О.В. Нестеренко [9], Л.П. Полякова [10], О.В. Половцев [11], О. В. Співаковський [12] тощо.

Незважаючи на велику кількість науковців, що займалися вивченням поставленої проблеми, внаслідок великої мінливості освітнього середовища, різного масштабу закладів освіти, наявності у них вже запроваджених систем чи підсистем управління структурними підрозділами чи закладами освіти у цілому, недостатньо освітленими залишаються питання взаємодії таких систем управління 3 інформаційними системами вищого рівня (Міністерство освіти і науки України, відповідні департаменти обласних державних адміністрацій чи управління районів, територіальних громад тощо), а також побудови єдиного освітнього середовища управління освітньою галуззю.

\section{Формулювання мети дослідження}

Головною метою дослідження постало завдання проаналізувати концептуальні підходи до цифрової трансформації освіти і науки з метою забезпечення ефективної комунікації в інформаційному просторі освітньої галузі.

\section{Викладення основного матеріалу дослідження}

Забезпечення ефективності державного управління в сучасних умовах розвитку інформаційного суспільства не може бути досягнуто без упровадження «цифрових» технологій у цій сфері. На безперечні переваги функціонування електронного урядування як форми державного управління, заснованої на застосуванні комп'ютерних та інших «цифрових» технологій, постійно звертають увагу. Саме тому в умовах становлення «цифрових» ринків та економік, коли громадяни стають фактично користувачами технологій, органи публічної влади повинні робити стратегічні інвестиції в інформаційно-комунікаційні технології. В іншому разі ці органи виявляться недостатньо готовими до нових моделей взаємодії та обслуговування, стануть заручниками старих, нестійких в довгостроковій перспективі моделей управління. Повільне, таке, що зволікає, запровадження технологічних інновацій у «цифрову» еру взагалі наражає на ризик виконання завдань та досягнення цілей державними установами, їх витрати збільшуються, неефективність зростає, вони все більше стають структурами, що не відповідають викликам часу, оскільки, як відомо, архаїчні структури не в змозі побудувати модернові системи, сфери або країни. Таким чином, держава передбачала підвищення ефективності функціонування своїх підсистем та процесів, проте це зробити поки що важко через відсутність дієвих інструментів «цифровізації» публічного управління.

Сьогодні всі говорять про підхід до публічного управління, що отримав назву «держава в смартфоні». Цей підхід не новий - він $є$ продовженням та розширенням застосування концепцій електронного урядування в державному управління. Інформаційна система управління людськими ресурсами (далі - ICУ ЛР) в органах публічної влади є одним з інструментів електронного урядування, впровадження якого сприятиме створенню умов для здійснення відкритого, прозорого та ефективного державного управління із застосуванням новітніх інформаційно-комунікаційних технологій 3 метою формування нового типу держави, політика якої орієнтована на задоволення потреб громадян. Але на сьогодні інформаційно-аналітичне забезпечення державних органів у сфері управління людськими ресурсами не відповідає потребам держави у проведенні реформи державного управління, іiі європейському вибору, європейським стандартам належного управління державою, а також сучасному рівню розвитку інформаційно-комунікаційних технологій.

Державне управління виокремлюється 3-поміж інших керованих систем тим, що має насамперед універсальний характер, зумовлений всеосяжним охопленням владних повноважень i функцій, потребами в регулюванні практично всіх видів суспільних ресурсів і сфер публічного життя.

Автоматизація та інформатизація систем управління відбувалася в різні роки, управлінські системи впроваджувалися в різних підрозділах нерівномірно. Якщо ж ураховувати також стрімке зростання характеристик комп’ютерної техніки, то обчислювальне середовище буде дуже неоднорідне. Ще однією причиною багатоплатформності може бути постійна турбота органів державної влади України щодо використання тільки легального програмного забезпечення або програмного забезпечення 
«з відкритим кодом», яке можна використовувати без придбання. У цьому разі в інформаційній системі управління можуть одночасно використовуватися 2-3 операційні системи та кілька обчислювальних платформ прикладного програмного забезпечення.

Розглядаючи систему державного управління як одну з підсистем соціальної системи, доцільно зазначити, що будь-яка підсистема, своєю чергою, теж поділяється на складові. Прикладом такої розгалуженості може виступати Кабінет Міністрів України, до складу якого входять різногалузеві профільні міністерства (центральні органи виконавчої влади), яким підпорядковуються підрозділи та організації по всій країні (територіальні підрозділи центральних органів виконавчої влади).

Згідно з постановою Кабінету Міністрів України від 16 жовтня 2014 р. № 630 «Про затвердження положення про Міністерство освіти і науки України» (далі - Положення) МОН України є центральним органом виконавчої влади, діяльність якого спрямовується і координується Кабінетом Міністрів України [13]. Саме це Міністерство очолює освітню галузь України як підсистему державного управління. До складу Міністерства входять департаменти різних напрямів, які керують дошкільною та загальною середньою, вищою освітою, науковою, міжнародною діяльністю тощо. Крім того, МОН України керує діяльністю відповідних департаментів, що входять до нього.

Освіта - багатофункціональна галузь. Ї̈ важливими функціями $є$ пізнавальна, виховна, розвивальна, координувальна, адаптаційна, профорієнтаційна, економічна, соціального захисту тощо. Вона одночасно постає як єдність п’яти якостей: як цінність, як процес, як результат, як послуга і як система [14].

Модернізація всієї вертикалі публічного управління неможлива без необхідних знань та освіти. Освіта - важлива сфера людської життєдіяльності, стратегічний чинник соціально-економічного, інтелектуального та духовного розвитку суспільства. За визначенням, прийнятим ХХ сесією Генеральної конференції ЮНЕСКО, під освітою розуміється процес і результат удосконалення здібностей і поведінки особистості, за якого вона досягає соціальної зрілості та індивідуального зростання. Освіта являє собою соціальний процес відтворення і нагромадження інтелектуального та культурного потенціалу [15].

Об'єктивно освіта належить до вищих цінностей людини і суспільства - вона є передумовою їх існування та розвитку. Саме у сфері освіти послідовно розвиваються здібності та формуються життєві прагнення всього населення. Чим вищий освітній рівень особистості, тим ширші їі можливості для створення оптимальних умов життя і праці. Освічена особистість - це не лише іії власне надбання, але й надбання суспільства в цілому.

Досягнення максимальної ефективності будь-якої діяльності $є$ результатом процесу проектування цієї діяльності та іiі здійсненням. Для ефективного формування та реалізації державної політики у сфері освіти і науки, прийняття управлінських рішень будь-якого рівня необхідна аналітична, статистична інформація. Відтак, функціонування цілісної системи збору, обробки та передачі інформації $\epsilon$ необхідною основою системного підходу до вирішення проблем та поставлення задач. Відсутність інтероперабельності державних реєстрів у сфері освіти і науки, інструментів обліку дітей на місцях призводить до дублювання даних, неефективного використання кадрових ресурсів, унеможливлення обміну даними між різними базами, зайвої бюрократизації процесів. Відтак, недостовірність даних в державних реєстрах унеможливлює прогнозування та оцінку ризиків результатів впроваджених політик. Тому цифрова трансформація освіти і науки передбачає, зокрема, трансформацію процесів збору, обробки та передачі інформації, а також доступу до актуальних статистичних даних для всіх заінтересованих сторін.

Так, у травні 2021 року МОН підготувало та пропонує для громадського обговорення проєкт Концепції цифрової трансформації освіти і науки на період до 2026 року, яка представляє комплексне системне стратегічне бачення цифрової трансформації цих сфер та відповідає засадам реалізації органами виконавчої влади принципів державної політики цифрового розвитку, що затверджені постановою Кабінету Міністрів України від 30 січня 2019 р. №56, а також пріоритетним напрямам та завданням (проєктам) цифрової трансформації на період до 2023 року, схваленим розпорядженням Кабінету Міністрів України від 17 лютого 2021 року № 365-р [16].

Схожі підходи були нами запропоновані у монографічному дослідження «Освітнє інформаційнокомунікаційне середовище: організаційний механізм формування» [17], де наведено теоретичне узагальнення та нове вирішення актуального наукового завдання в галузі державного управління щодо науково-теоретичного обгрунтування вдосконалення організаційного механізму формування освітнього інформаційно-комунікаційного середовища в контексті розширення концепцій електронного урядування, а також розроблення науково-практичних рекомендацій органам публічної влади щодо вдосконалення процесів управління освітньою галуззю на сучасному етапі.

У цьому дослідженні було запропоновано авторське визначення терміна «комплексний критерій оцінки ефективності освітнього інформаційно-комунікаційного середовища», що дає змогу не тільки отримати розуміння потреби запровадження такого організаційного механізму державного управління, але й оцінити його ефективність, а також проведено його змістовну декомпозицію, що дає краще 
розуміння принципів його застосування для оцінки ефективності освітнього інформаційнокомунікаційного середовища.

Середовище також може включати в себе додаткові сервіси, що реалізують інформаційну підтримку діяльності освітньої галузі за напрямками: адміністративне управління фінансами, організація навчального процесу, управління інформаційними ресурсами, тобто забезпечити комплексну організацію, контроль та оцінку ефективності цієї діяльності.

Саме це дає можливість сформулювати нам поняття «комплексний критерій оцінки ефективності освітнього інформаційно-комунікаційного середовища» як «сукупність оцінок ефективності механізмів формування та здійснення управлінських рішень, що включають в себе іх відповідність системному підходу, контрольованість, неперебійність та безпеку даних, раціональність та функціональне призначення».

Проведемо декомпозицію цього поняття:

1) відповідність системному підходу означає, що аналіз процесу управління освітньою галуззю, його вдосконалення, синтез нового управлінського процесу із заданими цілями відповідає загальним принципам підходу до управління складними системами;

2) контрольованість дає можливість втручання в процес управління на його різних стадіях із забезпеченням досягнення поставлених цілей у визначений час та з обмеженими ресурсами;

3) неперебійність та безпека даних показує, що система управління освітньою галуззю повинна працювати в режимі функціонування установ та організацій, забезпечуючи виконання службовцями та посадовими особами своїх обов'язків, і забезпечувати збереження даних відповідно до обраної політики безпеки (повноваження на виконання тих чи інших дій, розмежування прав доступу до різних рівнів інформації, можливість використання того чи іншого обладнання тощо);

4) раціональність та функціональне призначення вказує, що процес управління повинен забезпечувати потрібний набір функцій, маючи при цьому можливість до розширення свого функціоналу.

Зазначається, що в сучасному швидкозмінному світі слід використовувати управління, яке орієнтоване на розвиток і спирається на прогнозно-аналітичні розрахунки. Керівникам органів державного управління та органів місцевого самоврядування постійно доводиться ухвалювати конкретні рішення. Природно, що чим вищий рівень управління, тим більш вагомими та значущими $є$ відповідні рішення. Проте кількість чинників, що слід ураховувати в процесі ухвалення рішень, значно більша. Тобто, таке управління неможливе без формування сучасного інформаційно-комунікаційного середовища на різних рівнях управління.

Запропоноване нами освітне інформаційно-комунікаційне середовище дозволяє поліпшити управління освітньою галуззю на різних рівнях.

Його використання дасть можливість вирішити низку важливих завдань, а саме:

- аналіз часових значень певних показників дозволяє визначати, як змінюються процеси управління за часом та прогнозувати їх можливі показники в майбутньому. У нашому разі, наприклад, це можуть бути тенденції випуску школярів та їх вступ до закладів освіти вищих рівнів;

- аналіз витрат актуальний для будь-якої корпоративної структури, причому найбільше затребуваний аналіз у розрізі підпорядкованих ій установ. Це дає змогу міністерству чи іншій владній структурі отримувати інформацію про поточну діяльність та витрати, пов'язані з нею, у реальному режимі часу, оминаючи, у разі потреби, певні проміжні рівні або посадових осіб;

- освітне інформаційно-комунікаційне середовище дасть можливість простежувати зворотній зв'язок між установами (закладами вищої освіти), підрозділами (деканатами), відділами (кафедрами), фахівцями (викладачами), що дозволяє визначити «вузькі» місця процесу управління і вчасно зреагувати на можливі негативні тенденції.

Це середовище формується з використанням усіх досягнень сучасних інформаційних технологій, що передбачають як теоретичні напрацювання, так і їх практичну реалізацію - спеціалізовані засоби підтримки ухвалення рішень. Насамперед ідеться про комп’ютерну підтримку діяльності керівників різного рівня. Вирішувати це завдання мають комп'ютерні системи підтримки ухвалення рішень (СПУР, англ. Decision Support System - DSS).

Найбільшої ефективності можна досягти, використовуючи СПУР для управління великими системами, до яких належить також і держава, або великих галузей державного управління.

Державне управління освітньою галуззю неможливе без формування сучасного освітнього інформаційно-комунікаційного середовища на різних рівнях управління. Це середовище формується 3 використанням усіх досягнень сучасних інформаційних технологій, що передбачають як теоретичні доробки, так і їх практичну реалізацію. Одним із таких інструментів, що використовується в сучасних управлінських реаліях, є СПУР, розвиток яких почався ще в 50-60-их роках минулого сторіччя, але їх «вибуховий» розвиток прийшовся на кінець XX сторіччя. Сьогодні ж, з розвитком комунікаційних мереж 
(Інтернет, Інтранет) та відповідного обладнання, результатами роботи СПУР може користуватися навіть пересічний громадянин.

У Законі України «Про Національну програму інформатизації» подається таке визначення проекту інформатизації [18]: «Проект інформатизації - комплекс взаємопов'язаних заходів, як правило, інвестиційного характеру, що узгоджені за часом, використанням певних матеріально-технічних, інформаційних, людських, фінансових та інших ресурсів і мають на меті створення заздалегідь визначених інформаційних і телекомунікаційних систем, засобів інформатизації та інформаційних ресурсів, які відповідають певним технічним умовам і показникам якості».

Одним із ключових чинників сталого розвитку України й ефективним інструментом реалізації державної політики є проектний підхід, що спирається на концепцію створення цінності проекту [19].

Система управління проектом (СУП) - це набор інструментів, методів, методологій, ресурсів і процедур, що використовуються для управління проектом. СУП - це низка процесів і пов'язаних 3 ними функцій контролю, об'єднаних у функціональну єдність. Система управління проектами визначає цілі, межі і зміст робіт, організаційну структуру проекту, ролі учасників команди, процедури управління [20].

СУП - це комплекс організаційних, методичних, технічних, програмних та інформаційних засобів, спрямованих на підтримку та підвищення ефективності процесів проектування, планування та управління проектами, що реалізуються організацією. Структура і контекст системи управління проектами має особливості для кожної організації залежно від іiі юридичної форми та прийнятої організаційної структури [21].

Для того щоб забезпечити ефективну реалізацію проектів, потрібно: визначити кількість, послідовність і характер операцій, що складають цей процес; розробити (адаптувати) для кожної операції відповідні інструменти, методики, технічні засоби; визначити оптимальні умови протікання процесу реалізації завдань у часі й просторі. Для підвищення ефективності управління величезне значення має технологізація зазначеного процесу [20].

Проєкти розробляються для розв’язання певних проблем шляхом зміни ситуації. Причиною розроблення проєктів здебільшого є такі проблеми, що, по-перше, мають суперечливі різновекторні тенденції розвитку, і по-друге, потребують адекватного розв'язання. При цьому своєрідність проєктів виражається в тому, що головним експертом при їх оцінюванні виступає не держава або замовник проєкту, а суспільство.

«Сьогоднішня система освіти і науки має зазнати докорінних цифрових змін і відповідати світовим тенденціям цифрового розвитку для успішної реалізації кожною людиною свого потенціалу. На сьогодні дедалі більше професій потребують набуття високого рівня цифрових компетентностей i володіння новітніми технологіями. Ця потреба також поглиблена наслідками пандемії коронавірусу, яка загострила проблему розвитку та опанування технологіями в системі освіти задля забезпечення прав людей на якісну освіту», - зазначив Міністр освіти і науки України Сергій Шкарлет [16].

Так, набуття цифрових компетентностей стає базовою потребою для кожного, тому українська система освіти має забезпечувати формування цифрових компетентностей здобувачів освіти, педагогічних та науково-педагогічних працівників та розвиток цифрової інфраструктури та електронних сервісів у закладах освіти, в цілому.

Створення єдиного цифрового середовища, яке об'єднує всіх суб'єктів освітньої та наукової діяльності, що забезпечує простір для комунікації та обміну даними, значно зменшить бюрократичне навантаження системи освіти і науки та спростить управлінські процеси, які відбуваються в них.

На сьогодні дані, що обробляються в рамках однієї установи, у більшості випадків, знаходяться в незручному для аналізу вигляді. Традиційно необхідні дані в різних структурних підрозділах можуть збиратися в різних форматах і навіть у різних системах. Одночасно можуть функціонувати: програмний комплекс «Me.DOC», бази даних MS Access і таблиці MS Excel, а також бази даних у форматі власної облікової системи. Для отримання повної і достатньої інформації, потрібної для ухвалення управлінського рішення на рівні керівництва, слід аналізувати всі дані, що нагромаджуються в цих системах, як єдине ціле.

Існує можливість вирішити проблему, створивши інтерфейс, що дозволив би переводити дані 3 одного формату в іншій. Використання такого підходу може бути доцільним лише в тому разі, коли неможливо відмовитися від одночасного використання кількох систем. У такому разі ми отримаємо найбільш прийнятне рішення, що спирається на єдине джерело даних, тобто інформаційнокомунікаційне середовище.

Однією із головних проблем при створенні такого середовища може бути вироблення стратегії консолідації метаданих. Визначення вимог, що пред’являються до метаданих, може виявитися непростим завданням. Ключові сторони, яким можуть бути потрібні метадані, різноманітні і просторово роз'єднані. Це можуть бути як кінцеві користувачі або аналітики, так і програмні додатки або набори інструментів. Процес збору стандартних вимог не повинен надто розпливатися. Нами пропонується використовувати 
такий підхід для визначення метаданих закладу вищої освіти в межах освітнього інформаційнокомунікаційного середовища, що враховує специфічну природу метаданих («офіційних метаданих»):

- визначення ключових сторін для кожного елемента метаданих;

- віднесення кожного елемента метаданих до певної категорії: метаданих бізнесу, технічних метаданих або метаданих процесів;

- віднесення кожного елемента метаданих до категорії загальних або унікальних на основі їх використання в тих чи інших процесах.

Створення і модифікація елементів метаданих повинні здійснюватися за допомогою загального інтерфейсу.

Ця архітектура має кілька переваг:

- порівняно проста підтримка метаданих;

- спрощені процедури взаємодії між компонентами;

- прості процедури підготовки звітності.

Для функціонування та розвитку установи важливо не просто володіння інформацією. Багато що залежить від якості цієї інформації, уміння чітко і швидко визначати категорію показників, на підставі яких слід ухвалювати рішення, проводити аналіз певних значень цих показників з різним ступенем деталізації та обліком усіх параметрів, що мають на них вплив. ОІКС $є$ хорошим інструментом у вирішенні такого роду завдань.

Проєкт Концепції спрямований на подолання низки проблем, зокрема:

- низький рівень цифрових компетентностей учасників освітнього процесу;

- застарілий зміст освіти з навчальних предметів інформатичної галузі;

- недостатня кількість комп'ютерного обладнання та відсутність широкосмугового доступу до

Інтернету в закладах та установах системи освіти і науки;

- відсутність якісного цифрового освітнього контенту для здобуття освіти;

- відсутність актуальної, достовірної інформації про здобувачів освіти, педагогічних та науково-педагогічних працівників, а також науковців для прийняття управлінських рішень та моніторингу ефективності політик;

- забюрократизованість процесів внутрішнього документообігу закладів та установ освіти і науки;

- незручність отримання послуг та сервісів у системі освіти;

- недоступність наукових ресурсів та інфраструктур тощо.

Кінцевої мети планується досягти через такі стратегічні цілі:

- стратегічна ціль 1. «Цифрове освітнє середовище є доступним та сучасним»;

- стратегічна ціль 2. «Працівники сфери освіти володіють цифровими компетентностями»;

- стратегічна ціль 3. «Зміст освіти в галузі ІКТ відповідає сучасним вимогам»;

- стратегічна ціль 4. «Послуги та процеси у сфері освіти і науки є прозорими, зручними та ефективними»;

- стратегічна ціль 5. «Дані у сфері освіти і науки є доступними та достовірними».

Для кожної з цих цілей визначено шляхи та кроки їх досягнення на період до 2026 року.

Формування та реалізація державної політики з питань цифрової трансформації освіти і науки матиме вплив на ключові інтереси громадян, суб’єктів господарської діяльності, органів виконавчої влади.

Оскільки людина інтуїтивно відчуває, що рішення, що видаються інформаційно-аналітичною системою, не можуть бути абсолютно надійні в усіх можливих ситуаціях, то усвідомлюючи свою відповідальність за ухвалене рішення, вона не повністю довіряє машинним порадам, проте в цих системах повинні бути реалізовані такі функції:

- робота з великими масивами довідкової інформації та виробничими даними;

- наявність інформаційно-пошукової системи 3 повнофункціональним багатокритеріальним пошуком;

- наявність «ситуативної кімнати» або набору шаблонів щодо стандартних ситуацій розвитку господарської діяльності чи будь-якого її аспекта;

- можливість реалізації діалогового режиму прогнозування - «а що буде, якщо ...»; пріоритетами.

- можливість оптимізації вибору відповідного сценарію чи моделі за встановленими

Реалізація цієї Концепції матиме позитивний вплив на забезпечення правового регулювання, спрямованого на розвиток цифрового освітнього середовища, зокрема інфраструктури, цифрових компетентностей педагогічних, науково-педагогічних працівників та здобувачів освіти, створення цифрового освітнього контенту, автоматизацію та цифровізацію процесів регулювання та управління, підвищення рівня прозорості та зручності отримання послуг у сфері освіти, підвищення ефективності 
використання цифрових технологій, прискорення процесів цифрової трансформації в економіці та суспільстві України, що сприятиме розвитку цифрової економіки та конкурентоспроможності країни в глобальній економіці відповідно до напрямів Національної економічної стратегії.

В той же час «цифровізацію» варто розглядати як інструмент, а не як самоціль. При системному державному підході «цифрові» технології будуть значно стимулювати розвиток відкритого інформаційного суспільства як одного з істотних чинників розвитку демократії в Україні, підвищення продуктивності, економічного зростання, створення робочих місць, а також підвищення якості життя громадян України.

«Цифровізація» України має потребувати нових форм солідарності, партнерства і співробітництва. На підставі проаналізованих документів щодо створення «цифрових» просторів в Європі та світі нижче сформульовано висновки щодо основних принципів «цифровізації» освітньої галузі України.

\section{Висновки}

Держава повинна змінити пріоритети в своій політиці управління освітньою галуззю. Формування та використання єдиного освітнього середовища забезпечить умови для збору, збереження, поширення і комплексного використання всіх видів інформаційних ресурсів освітньої галузі, вільний доступ до них всіх зацікавлених сторін. Це, в свою чергу, підвищить ефективність діяльності органів державної влади, управління та місцевого самоврядування в цій сфері.

Технологічною основою для створення такого середовища можуть слугувати системи підтримки ухвалення рішень 3 інтеграцією сховищ даних різних типів, включаючи метадані. Використання таких інформаційних систем дає змогу ухвалювати ефективні рішення не тільки на основі доступної інформації, але й використовуючи сценарні або експертні підходи.

Маємо надію, що реалізація запропонованої Концепції дасть можливість здійснити цифрову трансформацію закладів освіти, в яких педагогічні та науково-педагогічні працівники, а також здобувачі освіти володіють цифровими компетентностями, забезпечені обладнаними цифровими, сучасними робочими місцями, а також доступом до цифрового контенту для персонального розвитку, навчання впродовж життя. Формування та реалізація державної політики, в тому числі розподіл державного замовлення та коштів на проведення наукових досліджень, будуть засновані на реальних персоніфікованих даних, які будуть централізовані та захищені. Науковці матимуть доступ до дослідницьких інфраструктур та справедливий доступ до отримання конкурсного фінансування.

\section{Список використаної літератури}

1. Про створення Єдиної державної електронної бази з питань освіти: постанова Кабінету Міністрів України від 13 липня 2011 р. №752. URL: http://zakon4.rada.gov.ua/laws/show/752-2011-\%D0\%BF (дата звернення: 20.03.2021).

2. Про затвердження Положення про Міністерство освіти і науки України: постанова Кабінету Міністрів України від 16 жовтня 2014 р. № 630. URL: https://zakon2.rada.gov.ua/laws/show/630-2014-п (дата звернення: 20.03.2021)

3. Нижник Н. Р., Мосов С. П. Державне управління в Україні: функція координування. Наукові записки Інституту законодавства Верховної Ради України. 2014. № 6. C. 111-116. URL: http://nbuv.gov.ua/UJRN/Nzizvru_2014_6_24 (дата звернення: 20.03.2021)

4. Бакуменко В. Д. Держава як об’єкт управління. Науковий вісник Академії муніципального управління. Серія: Управління. 2013. Вип. 3. С. 8-16. URL: http://nbuv.gov.ua/UJRN/Nvamu_upravl_2013_3_3 (дата звернення: 22.03.2021)

5. Корецький М., Сорока М., Калько $\overline{\mathrm{A}}$. Аналітичні аспекти організації та управління підготовкою кадрів для вищої школи в Національному університеті водного господарства та природокористування. Нова педагогічна думка. 2013. № 4. C. 10-12. URL: http://nbuv.gov.ua/UJRN/Npd_2013_4_4 (дата звернення: 22.03.2021)

6. Дзвінчук Д. І., Петренко В. П. Про вдосконалення управління освітою і наукою України на основі концепції інтелектуалізації. Теорія та практика державного управління $\mathrm{i}$ місцевого самоврядування. 2016. № 1. URL: http://nbuv.gov.ua/UJRN/Ttpdu_2016_1_6 (дата звернення: 22.03.2021)

7. Лопушинський I. П., Ковнір О. І. Свропейський та світовий досвід реформування освіти в процесі децентралізації влади. Педагогічний альманах. 2017. Вип. 33. С. 230-237. URL: http://nbuv.gov.ua/UJRN/pedalm_2017_33_39 (дата звернення: 22.03.2021)

8. Бідюк П. І., Кожухівський А. Д., Кожухівська О. А. Система підтримки прийняття рішень для аналізу і прогнозування стану підприємства. Радіоелектроніка, інформатика, управління. 2013. № 1. С. 128-136. URL: http://nbuv.gov.ua/UJRN/riu_2013_1_22 (дата звернення: 22.03.2021)

9. Нестеренко О.В. Основи побудови автоматизованих інформаційно-аналітичних систем органів державної влади. К.: Наук. Думка, 2005. 628 с. 
10. Полякова Л. П., Криштопа А. О. Механізми державного управління вищою освітою на основі використання інформаційного середовища. Теорія та практика державного управління. 2009. Вип. 3. С. 53-58. URL: http://nbuv.gov.ua/UJRN/Tpdu_2009_3_10 (дата звернення: 22.03.2021)

11. Половцев О.В. Системний підхід та інформаційні технології підтримки прийняття рішень в державному управлінні: монографія. Донецьк: Східний видавничий дім, 2010. 206 с.

12. Співаковський О. В. Львов М. С., Кравцов Г. М. Інноваційні методи управління інформаційними активами вищого навчального закладу. Комп’ютер у школі та сім’ї. 2013. № 3. C. 3-7. URL: http://nbuv.gov.ua/UJRN/komp $2013 \quad 32$ (дата звернення: 23.03.2021)

13. Про затвердження положення про Міністерство освіти і науки України: постанова Кабінету Міністрів України від 16 жовтня 2014 р. № 630. URL: https://zakon2.rada.gov.ua/laws/show/630-2014$\% \mathrm{D} 0 \% \mathrm{BF}$ (дата звернення: 23.03.2021)

14. Якісна освіта - запорука самореалізації особистості / за заг. ред. С. М. Ніколаєнка, В. В. Тесленка. - К.: Пед. преса, 2007. - 176 с.

15. Ніколаєнко С. М. Вища освіта - джерело соціально-економічного і культурного розвитку суспільства / С. М. Ніколаєнко. - К.: Знання, 2005. - 319 с.

16. Концепція цифрової трансформації освіти і науки: МОН запрошує до громадського обговорення. URL: $\quad$ https://mon.gov.ua/ua/news/koncepciya-cifrovoyi-transformaciyi-osviti-i-nauki-mon-zaproshuye-dogromadskogo-obgovorennya (дата звернення: 23.03.2021)

17. Дурман О.Л. Освітнє інформаційно-комунікаційне середовище: організаційний механізм формування: монографія / Дурман О. Л.; за наук. ред. проф. І. Лопушинського. - Херсон: Вид-во ФОП Вишемирський В.С., 2019. - 244 с.

18. Про Національну програму інформатизації: Закон України від 4 лютого 1998 року № 74/98-ВР. URL: https://zakon.rada.gov.ua/laws/show/74/98-\%D0\%B2\%D1\%80 (дата звернення: 23.03.2021)

19.Безверхнюк Т. Система управління соціальним проектом. Актуальні проблеми державного управління. 2014. Вип. 1. С. 9-12. URL: http://nbuv.gov.ua/UJRN/apdyo_2014_1_5. (дата звернення: 23.03.2021)

20. Науковий супровід, моніторинг та оцінка ефективності соціальних проектів / О. О. Яременко, О. Р. Артюх, О. М. Балакірєва та ін. К.: ДЦССМ. 2002. 132 с.

21. Бушуєв С. Д., Ярошенко Р. Ф. Управління інноваційними програмами на основі застосування системи знань Р2М та технології Кайзен. Науковий вісник Міжнародного гуманітарного університету. 2010. № 2. C. 9-12.

\section{References}

1. On the creation of the Unified State Electronic Database on Education: Resolution of the Cabinet of Ministers of Ukraine of July 13, 2011 №752. URL: http://zakon4.rada.gov.ua/laws/show/752-2011-\%D0\%BF (access date: 20.03.2021) [in Ukrainian]

2. On approval of the Regulation on the Ministry of Education and Science of Ukraine: Resolution of the Cabinet of Ministers of Ukraine of October 16, 2014 № 630. URL: https://zakon2.rada.gov.ua/laws/show/6302014-p (date appeal: March 20, 2021) [in Ukrainian]

3. Nyzhnyk N.R., Mosov S.P. Public administration in Ukraine: the function of coordination. Naukovi zapysky Instytutu zakonodavstva Verkhovnoyi Rady Ukrayiny. 2014. № 6. pp. 111-116. URL: http://nbuv.gov.ua/UJRN/Nzizvru_2014_6_24 (access date: 20/03/2021) [in Ukrainian]

4. Bakumenko V.D. The state as an object of government. Naukovyy visnyk Akademiyi munitsypal'noho

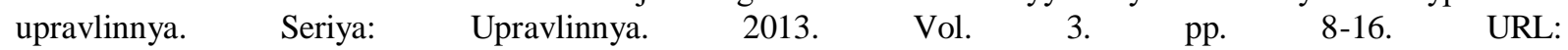
http://nbuv.gov.ua/UJRN/Nvamu_upravl_2013_3_3 (access date: March 22, 2021) [in Ukrainian]

5. Koretsky M., Soroka M., Kalko A. Analytical aspects of the organization and management of training for higher education at the National University of Water Management and Environmental Sciences. Nova pedahohichna dumka. 2013. № 4. pp. 10-12. URL: http://nbuv.gov.ua/UJRN/Npd_2013_4_4 (access date: 22/03/2021) [in Ukrainian]

6. Dzvinchuk D.I., Petrenko V.P. On improving the management of education and science of Ukraine on the basis of the concept of intellectualization. Teoriya ta praktyka derzhavnoho upravlinnya i mistsevoho samovryaduvannya. 2016. № 1. URL: http://nbuv.gov.ua/UJRN/Ttpdu_2016_1_6 (access date: 22.03.2021) [in Ukrainian]

7. Lopushinsky I.P., Kovnir O.I. European and world experience of education reform in the process of decentralization of power. Pedahohichnyy al'manakh. 2017. Vol. 33. pp. 230-237. URL: http://nbuv.gov.ua/UJRN/pedalm_2017_33_39 (access date: 22/03/2021) [in Ukrainian]

8. Bidyuk P.I., Kozhukhovsky A.D., Kozhukhovskaya O.A. Decision support system for analysis and forecasting of the enterprise. Radioelektronika, informatyka, upravlinnya. 2013. № 1. pp. 128-136. URL: http://nbuv.gov.ua/UJRN/riu_2013_1_22 (access date: 22/03/2021) [in Ukrainian] 
9. Nesterenko O.V. Fundamentals of building automated information and analytical systems of public authorities. K .: Nauk. Dumka, 2005. 628 p. [in Ukrainian]

10. Polyakova L.P., Kryshtopa A.A. Mechanisms of public administration of higher education based on the use of information environment. Teoriya ta praktyka derzhavnoho upravlinnya. 2009. Vol. 3. pp. 53-58. URL: http://nbuv.gov.ua/UJRN/Tpdu_2009_3_10 (access date: 22/03/2021) [in Ukrainian]

11. Polovtsev O.V. System approach and information technologies of decision support in public administration: monograph. Donetsk: Skhidnyy vydavnychyy dim, 2010. 206 p. [in Ukrainian]

12. Spivakovsky O.V., Lvov M.S., Kravtsov G.M. Innovative methods of managing information assets of higher education. Komp'yuter u shkoli ta sim'yi. 2013. № 3. pp. 3-7. URL: http://nbuv.gov.ua/UJRN/Komp_2013_3_2 (access date: March 23, 2021) [in Ukrainian]

13. On approval of the regulations on the Ministry of Education and Science of Ukraine: Resolution of the Cabinet of Ministers of Ukraine of October 16, 2014 № 630. URL: https://zakon2.rada.gov.ua/laws/show/6302014-\%D0\% BF (access date: March 23, 2021) [in Ukrainian]

14. Quality education - the key to self-realization of the individual / for general. ed. S.M. Nikolaenko, V.V. Teslenko. - K .: Ped. presa, 2007. - 176 p. [in Ukrainian]

15. Nikolaenko S.M. Higher education - a source of socio-economic and cultural development of society / S.M. Nikolaenko. - K .: Znannya, 2005. - 319 c. [in Ukrainian]

16. The concept of digital transformation of education and science: MES invites to public discussion. URL: https://mon.gov.ua/en/news/koncepciya-cifrovoyi-transformaciyi-osviti-i-nauki-mon-zaproshuye-dogromadskogo-obgovorennya (access date: March 23, 2021) [in Ukrainian]

17. Durman O.L. Educational information and communication environment: organizational mechanism of formation: monograph / Durman O.L.; for science. ed. prof. I. Lopushinsky. - Kherson: Vyd-vo FOP Vyshemyrs'kyy V.S., 2019. - 244 p. [in Ukrainian]

18. On the National Informatization Program: Law of Ukraine of February 4, 1998 № 74/98-VR. URL: https://zakon.rada.gov.ua/laws/ show / 74 / 98-\% D0\% B2\% D1\% 80 (access date: March 23, 2021) [in Ukrainian]

19. Bezverkhnyuk T. Social project management system. Aktual'ni problemy derzhavnoho upravlinnya. 2014. Vol. 1. pp. 9-12. URL: http://nbuv.gov.ua/UJRN/apdyo_2014_1 5 (access date: March 23, 2021) [in Ukrainian]

20. Scientific support, monitoring and evaluation of the effectiveness of social projects / O.O. Yaremenko, O.R. Artyukh, O.M. Balakireva and others. K .: DCSSM. 2002. 132 p. [in Ukrainian]

21. Bushuyev S.D., Yaroshenko R.F. Management of innovative programs based on the application of P2M knowledge system and Kaizen technology. Naukovyy visnyk Mizhnarodnoho humanitarnoho universytetu. 2010. № 2. pp. 9-12. [in Ukrainian] 